\title{
Coping strategy for covid-19 in primary health care: experience report in Salvador-BA
}

\author{
Estratégia de enfrentamento para covid-19 na atenção primária \\ à saúde: relato de experiência em Salvador-BA \\ Estrategia de enfrentamiento del covid-19 en atención primaria \\ de salud: informe de experiencia en Salvador-BA
}

\author{
Lélia Mendes Sobrinho de Oliveira ${ }^{a, b}$ \\ Nildete Pereira Gomes ${ }^{a}$ \\ Emanuela Santos Oliveira ${ }^{a}$ \\ Alice de Andrade Santos ${ }^{a}$ \\ Larissa Chaves Pedreira ${ }^{a}$
}

How to cite this article: Oliveira LMS, Gomes NP, Oliveira ES, Santos AA, Pedreira LC. Coping strategy for covid-19 in primary health care: experience report in Salvador-BA. Rev Gaúcha Enferm. 2021;42(spe):e20200138. doi: https://doi.org/10.1590/19831447.2021.20200138

\footnotetext{
Universidade Federal da Bahia (UFBA), Escola de Enfermagem. Salvador, Bahia, Brasil.

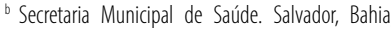
Brasil.
}

\section{ABSTRACT}

Objective: To report the experience of actions to confront the Coronavirus developed by primary health care in the municipality of Salvador, Bahia, Brazil.

Methods: It is an account of the experience carried out by a nurse from the health management of the city of Salvador, in the fight against the Coronavirus, without a period from February 26 to April 26, 2020.

Results: A flow of action was elaborated to confront the Coronavirus in the primary health care network, aiming to implement conducts in the face of the pandemic. The professionals were trained to identify suspected cases of contamination and to guide or refer these people to the health service.

Conclusion: It was concluded that the construction of a flow to attend suspected cases of contamination by Coronavirus was relevant to mitigate the impacts, protecting the community and professionals involved.

Keywords: Primary health care. Coronavirus infections. Severe acute respiratory syndrome. Nurse practitioners. Pandemics.

\section{RESUMO}

Objetivo: Relatar a experiência de ações de enfrentamento ao Coronavírus desenvolvidas pela atenção primária à saúde do município de Salvador, Bahia, Brasil.

Métodos: Trata-se de um relato da experiência realizado por uma enfermeira da gestão de saúde do município de Salvador, no enfrentamento ao Coronavírus, no período de 26 de fevereiro a 26 de abril de 2020.

Resultados: Foi elaborado um fluxo de ação para enfrentamento ao Coronavírus na rede de atenção primária à saúde, objetivando implementar condutas frente à pandemia. Os profissionais foram treinados para identificar casos suspeitos de contaminação e orientar ou encaminhar essas pessoas ao serviço de saúde.

Conclusão: Concluiu-se que a construção de um fluxo para atendimento de casos suspeitos de contaminação pelo Coronavírus foi relevante para amenizar os impactos, protegendo comunidade e profissionais envolvidos

Palavras-chave: Atenção primária à saúde. Infecções por coronavírus. Síndrome respiratória aguda grave. Profissionais de enfermagem. Pandemias.

\section{RESUMEN}

Objetivo: Informar sobre la experiencia de acciones para enfrentar el Coronavirus desarrollado por la atención primaria de salud en la ciudad de Salvador, Bahía, Brasil.

Métodos: es un relato de la experiencia llevada a cabo por una enfermera de la gerencia de salud de la ciudad de Salvador, en la lucha contra el coronavirus, período del 26 de febrero al 26 de abril de 2020

Resultados: Se elaboró un flujo de acción confrontar el Coronavirus en la red de atención primaria de salud, con el objetivo de implementar conductas frente a la pandemia. Los profesionales fueron capacitados para identificar casos sospechosos de contaminación y para guiar o derivar a estas personas al servicio de salud.

Conclusión: Se concluyó que la construcción de un flujo para atender casos sospechosos de contaminación por Coronavirus fue relevante para mitigar los impactos, protegiendo a la comunidad y los profesionales involucrados.

Palabras clave: Atención primaria de salud. Infecciones por coronavirus. Síndrome respiratorio agudo grave. Enfermeras practicantes. Pandemias. 


\section{INTRODUCTION}

The COVID-19 disease is a highly transmissible and pathogenic viral infection, caused by the new Severe Acute Respiratory Syndrome Coronavirus (SARS-CoV-2), which appeared in Wuhan, China, and has spread worldwide. Its transmission between humans occurs through close contact with an infected person, exposed to respiratory droplets or aerosols, coughing and sneezing, after inhalation through the nasal or oral cavity ${ }^{(1)}$. Currently, there are some questions about the possibility of human-animal transmission and of animals serving as carriers of the virus to other animals or humans. However, there is still no scientific proof that animals are important transmitters in the epidemiological chain of COVID-19(2).

On January 30, 2020, the World Health Organization (WHO) declared the outbreak of COVID-19 as the sixth Public Health Emergency of International Importance after H1N1 (2009), Polio (2014), Ebola in West Africa (2014), Zika (2016) and Ebola in the Democratic Republic of the Congo (2019), being considered a pandemic as it threatens many people simultaneously worldwide ${ }^{(1)}$.

The current estimate of the average incubation period for COVID-19 is 6.4 days, ranging from 2.1 days to 11.1 days (2.5th to 97.5 th percentile) $)^{(3)}$. The main early symptoms include fever, cough, muscle pain and dyspnea. Some patients had atypical symptoms, such as diarrhea and vomiting ${ }^{(4)}$. The period between the onset of symptoms and death ranged from 6 to 41 days, with a median of 14 days ${ }^{(5)}$.

Several studies ${ }^{(6-8)}$ in the world have been developed in order to identify a way to prevent its expansion. However, there are no specific antiviral drugs or vaccines against COVID-19 infection for potential therapy in humans. Thus, special attention and efforts to protect or reduce transmission are being applied to the most vulnerable populations, such as the elderly, immunosuppressed, or those with chronic diseases - especially diabetes and hypertension - and health professionals. The Ministry of Health recommends measures of social distance, respiratory etiquette and hand hygiene as the only and most efficient measures to combat the pandemic ${ }^{(9)}$.

The Brazilian population is estimated at 211 million inhabitants ${ }^{(10)}$, of which, $14.26 \%$ fit the age profile of the disease. However, new cases are advancing rapidly across the country. Therefore, measures were adopted by the Ministry of Health (2020), such as: laboratory surveillance, infection control protocols, health surveillance through health measures in ports and airports, school closures, communication and risk management, among others ${ }^{(11)}$.
In Bahia, there are 198,767 cases of COVID-19 confirmed. Of these,180,488 patients have recovered,14,212 are being monitored by epidemiological surveillance, and 4067 resulted in deaths ${ }^{(12)}$. This number accounts for all records up to August 11,2020, with the largest number of confirmed cases being in the municipality of Salvador, with 2013 deaths ${ }^{(12)}$.

Faced with the pandemic, the highly complex rear system works with the creation of hospital beds, equipped intensive care units (ICUs), field hospitals and an increase in the number of human resources in health. However, actions in Primary Health Care (PHC) to contain viral proliferation, sensitizing, guiding the population as to the measures to be taken to prevent the transmission of the virus and COVID-19, have been shown to be essential in protecting people and the health system.

PHC organizes care for users to access the Unified Health System (SUS), being considered the main gateway for individuals in this system. Thus, it promotes accessibility, coordination, continuity and integrality of care, with a view to meeting the population's health needs. The main physical structures of this model of care are the Basic Health Units (UBS), with or without a family health strategy, composed of a multidisciplinary team consisting of doctor, nurse, nursing technician, dentist, community health agents (CHA), among others, that offer a variety of services, making it possible to meet user health needs, referring them to other levels of care if needed ${ }^{(13)}$. In this sense, PHC has been a fundamental mechanism to face COVID-19 and to control the high complexity overhead.

In view of this context and importance of the theme, the study aims to: report the experience of actions developed by Primary Health Care in the city of Salvador, Bahia, Brazil, to confront the Coronavirus.

\section{DEXPERIENCE REPORT}

The work is based on the theoretical-methodological precept of the historical-cultural perspective, in which the practices shared by professionals intertwine with the sociological of health work in primary care.

The historical-cultural perspective is a theory that favors transformation and understands mankind as active participants in their own existence. This theory explains human learning from social interactions, where there is a relationship between language and cognitive development in the teaching and learning processes. At each moment of their development, the individual acquires the means to intervene competently in their world and themselves ${ }^{(14)}$. 
It is an experience report made by a health management nurse in the city of Salvador, Bahia, Brazil, on the performance of integrated care professionals, such as nurses, doctors, physiotherapists and nursing technicians, in coping with Coronavirus, from February 26 to April 26, 2020.

The PHC network in the city of Salvador has 121 Health Units, of which 46 are Basic Units without Family Health and 75 are Basic Units with a Family Health strategy, with:250 Family Health teams implemented,3 Street Clinic teams, and 11 Family Health Support Centers - NASF. In its administrative organization, $\mathrm{PHC}$ is divided into 12 health districts that characterize health territories. Currently, about 45.7\% of the population in Salvador is covered by PHC services ${ }^{(15)}$.

The action to confront COVID-19 took place in the PHC network, aiming to implement conducts in the face of the pandemic. To this end, the first measure adopted was the expansion of technical support from the Strategic Information Center for Health Surveillance in Salvador (CIEVS SSA), an organ linked to the Municipal Health Department (SMS), which began operating 24 hours a day, uninterruptedly.

From then on, through remote meetings with representatives of different action areas in the municipality's health in the urgency/emergency, primary care, municipal clinical analysis laboratory, coordinators of the health districts thematic fields, among others, a flowchart was created for interdisciplinary operationalization of care for suspected or confirmed cases of contamination by COVID-19. It is worth noting that the flowchart was designed by the authors based on the SMS Technical Note ${ }^{(9)}$. In this way, all users who sought the UBS showing symptoms of Flu Syndrome (FS), such as: fever measured or referred above $38^{\circ} \mathrm{C}$, cough, muscle pain, head or throat pain and respiratory distress or symptoms of Severe Acute Respiratory Syndrome (SARS), as symptoms of FS plus dyspnea or shortness of breath, should be referred, according to the severity of their clinical presentation, either to home isolation or to the most complex health unit, such as the Emergency Care Unit (UPA) ) and 24 hour Care Unit (PA). In addition, all suspected cases should be reported to the corresponding health district in the region.

In this way, users who sought the UBS, with or without a Family Health Strategy (FHS), went through differentiated reception, consisting of a nurse, a doctor and a nursing technician, who prioritized the suspected FS and more vulnerable groups, such as the elderly, pregnant/postpartum women and patients with chronic diseases, whose complaints were identified after a systematic investigation by the health team. Upon reception, users who had a suspicious condition, compatible with the need for rest, hydration, adequate food, analgesics and antipyretics (if necessary) were instructed to remain in home isolation for 14 days, starting from the date of onset of symptoms. In home isolation, these patients were then monitored every 48 hours, by telephone contact or home visit, by any professional of the team that welcomed them, with a view to identifying the evolution or regression of the symptoms, adding all the data in the patient's medical record. Cases assessed as serious would be referred to a medium or high complexity unit, aiming at prompt service to the needs presented by the user (Figure 1).

It is worth noting that another preventive and control measure carried out by UBS was to reinforce daily preventive actions for the population through visual educational materials, fixed and available at the entrance of services and in strategic places, guiding the appropriate preventive measures, such as frequently washing hands with soap and water, or using 70\% alcohol, avoid touching eyes, nose and mouth, use disposable tissue for nasal hygiene, use a mask, keep at least a 1 meter distance from other people, avoid handshakes, hugs and kisses, avoid agglomerations, clean and disinfect frequently touched objects and surfaces.

Another measure to combat COVID-19, sent by APS, was the anticipation of the national campaign of immunization against Influenza, mainly in an attempt to avoid overloading the hospital network with other flu situations. This measure used the drive-thru service in three parts of the city as a strategy to keep people away, to serve the elderly and health professionals, as they are groups at higher risk for contamination. In this way, central management was able to guarantee greater safety for this public. Those who did not have the support of a car went to a health center closest to their residence, always emphasizing the adoption of appropriate precautions.

In order to reinforce the staff of professionals in the war against COVID-19 in the PHC units, 388 job vacancies were offered through the special administrative law regime (REDA). As it is an emergency strategy, the selection of candidates occurred through curriculum analysis. 


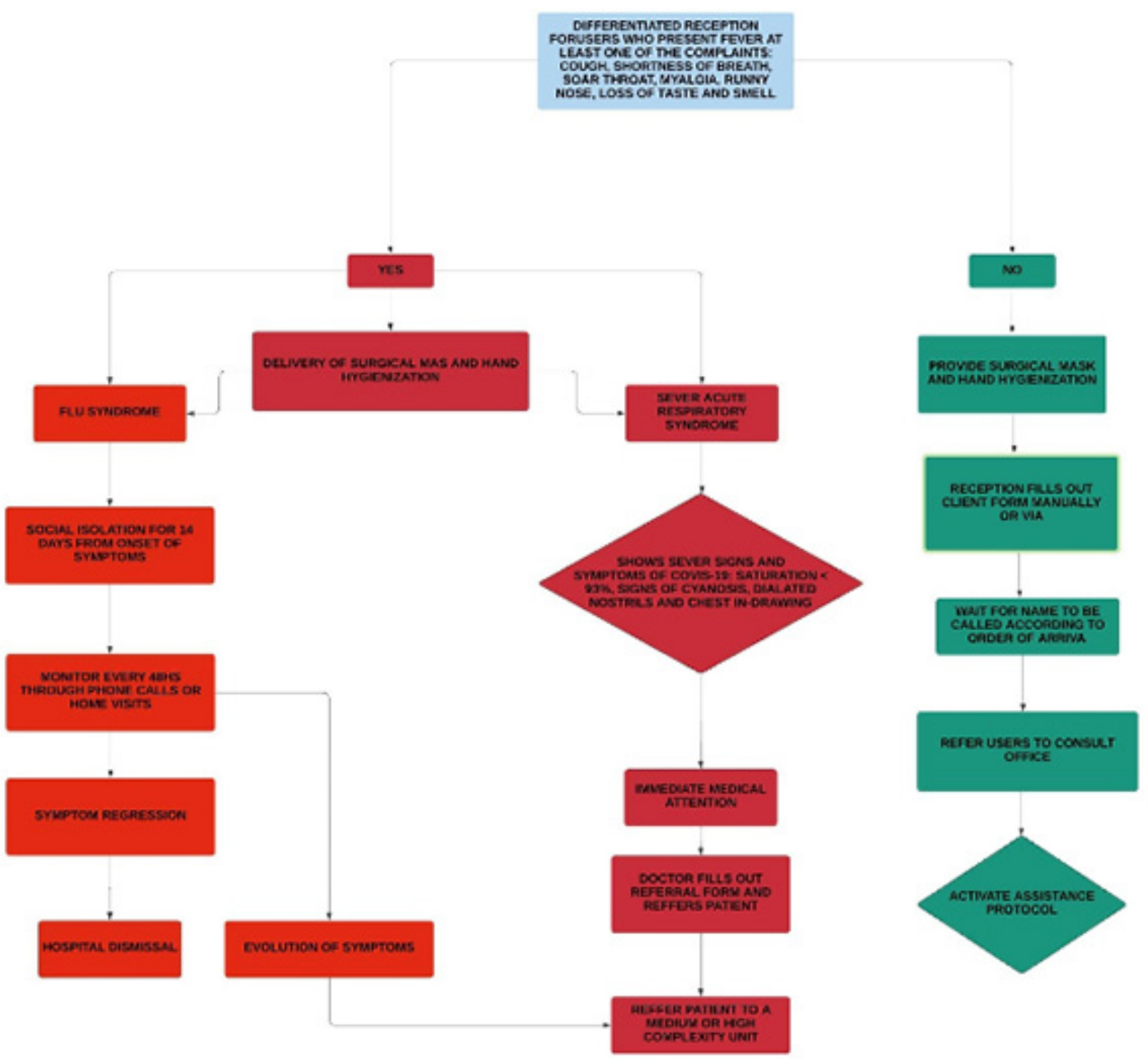

Figure 1 - Service flowchart for users suspected or confirmed as COVID-19 positive Source: Based on SMS Technical Note No. 05/2020 $0^{19}$.

\section{DISCUSSION}

The construction of a flow to deal with suspected cases of contamination by COVID-19, and control strategies, was extremely relevant for $\mathrm{PHC}$, helping to guide the population, avoiding overload in the capital's urgency and emergency network, and enabling quick and effective access to early diagnosis and actions to contain and spread the disease. Thus, health professionals were able to intervene with the necessary guidelines and conduct to avoid and/or minimize health problems, in addition to reducing the chance of contagion.

Regarding home care, CHAs stand out among the professionals working in PHC, as they carry out visits and clinical home monitoring of suspected cases more frequently, informing the team of complications arising at the patient's home. The proper use of personal protective equipment (PPE's) is of fundamental importance, as is following the 
guidelines of the established assistance flow, in order to avoid contamination ${ }^{(9)}$.

To meet the strategy to combat COVID-19 in PHC, health management provided nursing professionals, doctors and higher education technicians (physiotherapist, psychologist, social worker, among others) in health units with training on information for facing this pandemic. Armed with this knowledge, professionals provided guidance to users, during consultation and home visits, informing possible ways to avoid agglomeration, COVID-19 contamination and transmission. In this way, the learning process was relevant to qualify health professionals about Coronavirus, so that they provided assistance to users, guiding them in a safer and more efficient way.

In the context of learning, the historical-cultural theory ${ }^{(14)}$ stands out, based on the psychological functions of the individual, described as elementary, with biological development, and higher, of socio-cultural origin. This theory emphasizes the relevance of the concept of mediation, in which elements such as signs and words provide the individual's relationship with the external environment ${ }^{(16)}$. Language becomes the main mediator for the construction of higher functions, especially in teaching situations that promote the appropriation of knowledge and self-regulation ${ }^{(17)}$.

In this context, social mediation contemplates the dialectical relationship between the individual and society for mutual construction ${ }^{(14)}$. Thus, it is inferred that all learning is

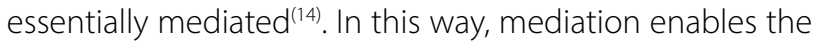
internalization of knowledge with the development of the subject and, consequently, the formation of consciousness ${ }^{(16)}$.

With regard to the Coronavirus pandemic, the historical-cultural theory corroborates the importance of mediation with the use of language and signs in the learning process with a view to apprehending knowledge about the guidelines for measures to prevent and combat COVID-19.

A study ${ }^{(7)}$ states that China used recommendations that the population frequently perform hand hygiene, use of masks, isolation and social distance, as well as quarantine, as a strategy. These actions had a positive result in minimizing the outbreak in the country ${ }^{(7)}$. Thus, the importance of providing guidance to the population in this process is emphasized, which also contributes to avoid situations of panic.

The professionals who receive the population in their first contact with the health service need to know and be aware of the initial symptoms caused by COVID-19. A study corroborates that the most common symptoms presented by individuals infected by the virus are fever, cough, fatigue and dyspnea ${ }^{(8)}$. With the current scenario, as soon as they present the first symptoms, people should seek a UBS closer to their home, for clinical evaluation, differential diagnosis and necessary referral $l^{(9)}$.

Therefore, the organization of health services is defined by reference and counter-reference through compliance with flows and pacts, which guarantee accessibility and comprehensive care at all levels of complexity, for the user ${ }^{(18)}$. However, given the situation of the pandemic, users assisted at UPAS and in serious condition due to COVID-19 are submitted to the bed regulation center of the state and municipality, to be transferred to a more complex care unit.

It is worth noting that this flow favored the screening of symptomatic cases, providing earlier care and referral to the specialized network in the most effective way, with a view to reducing complications in the evolution of the disease. It is important to highlight that the care provided to asymptomatic users or those presenting other care demands, such as the need to continue the hypertension and diabetes treatments, application of medication, vaccine and dressings, was maintained in the health units ${ }^{(15)}$.

It is also noticed that the implementation of the service flows caused impacts on the targeting and accessibility of the users attended in the UBS, reducing the overcrowding in the UPAS and reference hospitals. This fact is due to the allocation of users according to the case and clinical management, avoiding unnecessary input costs. This intervention also provided high complexity units with bed availability for the most serious cases of COVID-19, as indicated by the Ministry of Health ${ }^{(11)}$.

Another important issue to be considered was the implementation of early actions to immunize populations vulnerable to Influenza. The 22nd National Influenza Vaccination Campaign was anticipated by the Ministry of Health, due to the Coronavirus pandemic. The campaign started in Salvador, in March 2020, with the intention of immunizing the population against influenza to reduce the circulation of this virus and the impact on healthcare services due to the similarity with the signs and symptoms of COVID-19(19). In view of the potential of the influenza virus to cause disease with severe respiratory symptoms, early immunization allows to reduce the risks of respiratory infection, hospitalization and mortality ${ }^{(20)}$. Research that describes the trend of mortality rates due to cerebrovascular diseases (CVD) in the elderly, between 1980 and 2012, before and after influenza vaccination campaigns, concluded that there was a reduction in CVD mortality in the elderly population ${ }^{(21)}$. Thus, the importance of vaccination is noted in order to minimize the health risks of the population.

While these actions are provided, studies are taking place in search of solutions, treatment and cure for the new virus. With the lack of a vaccine that inhibits SARS-CoV-2 infection 
until today, the fight against COVID-19 consists of isolating and investigating effective drugs for reversing the severe form of the disease. Based on studies ${ }^{(7-8,11)}$, it is known that social distancing is an effective measure against the spread of the virus, thus reducing the number of cases.

\section{CONCLUSION}

It was concluded that the construction of a flowchart to care for suspected or confirmed cases of COVID-19contamination was relevant to Primary Health Care. This instrument, coupled with guidelines for social distancing actions, the vaccination campaign and technical support from committees, made it possible to guide and qualify health professionals to act quickly and effectively in identifying the symptoms of COVID-19.

With regard to nursing practices, the implementation of the flowchart made it possible to undertake the systematization of care, facilitating work operations, making them more dynamic and accurate, and guaranteeing qualified, safe care. In addition, it makes administrative organization feasible, since it provides clarity of flows, as well as greater visibility of the outcome of processes.

The study presented the reduced number of publications and little clinical experience with COVID-19, due to the originality of the theme in question, as a limitation. Thus, socializing the experience with COVID-19 coping actions is fundamental to understanding the advantages that teams can bring to health services in Primary Health Care in times other than during a pandemic, as they enable the achievement of better results if shared and developed with the collaboration and cooperation of all.

\section{REFERENCES}

1. Yoo JH. The fight against the 2019-nCoV outbreak: an arduous march has just begun. J Korean Med Sci. 2020;35(4):e56. doi: https://doi.org/10.3346/ jkms.2020.35.e56

2. Lopes OFM, Gomes NRS, Freitas DRJ, Evangelista LSM. COVID-19 e os animais domésticos: há alguma evidência de relação entre eles? J Health Biol Sci. 2020;8(1):1-6. doi: https://doi.org/10.12662/2317-3076jhbs.v8i1.3225. p1-6.2020

3. Backer JA, Klinkenberg D, Wallinga J. Incubation period of 2019 novel coronavirus (2019-nCoV) infections among travellers from Wuhan, China, 20-28 January 2020. Euro Surveill. 2020;25(5):pii=2000062. doi: https://doi. org/10.2807/1560-7917.ES.2020.25.5.2000062

4. Sun J, He WT, Wang L, et al. COVID-19: epidemiology, evolution, and crossdisciplinary perspectives. Trends Mol. Med. 2020;26(5):483-95. doi: https:// doi.org/10.1016/j.molmed.2020.02.008

5. Wang W, Tang J, Wei F. Updated understanding of the outbreak of 2019 novel coronavirus (2019-nCoV) in Wuhan, China. J Med Virol. 2020;92(4):441-7. doi: https://doi.org/10.1002/jmv.25689
6. Li H, Liu SM, Yu XH, et al. Coronavirus disease 2019 (COVID-19): current status and future perspectives. Int J Antimicrob Agents. 2020;20:105951. doi: https:// doi.org/10.1016/j.jiantimicag.2020.105951

7. Xie M, Chen Q. Insight into 2019 novel coronavirus - an updated intrim review and lessons from SARS-CoV and MERS-CoV. Int J Infect Dis. 2020;94:119-24. doi: https://doi.org/10.1016/j.ijid.2020.03.071

8. Wu D, Wu T, Liu Q, Yang Z. The SARS-CoV-2 outbreak: what we know. Int J Infect Dis. 2020;94:44-8. doi: https://doi.org/10.1016/j.ijid.2020.03.004

9. Secretaria Municipal de Saúde do Município de Salvador (BR). Atenção Primária à Saúde, Nota Técnica no 05/2020 - novo Coronavírus: Orientações para organização da Atenção Primária à Saúde no enfrentamento ao Novo Coronavírus (COVID-19) no município do Salvador. Salvador: SMS; 2020 [cited 2020 Apr 14]. Available from: http://www.saude.salvador.ba.gov. br/wp-content/uploads/2020/06/Nota-Tecnica-DASAPS-N-05-de-2020Atualizaca0-09.04.pdf

10. Instituto Brasileiro de Geografia e Estatística [Internet]. Rio de Janeiro: IBGE; c2020 [cited 2020 Apr 13]. População; [about 1 screen]. Available from: https:// www.ibge.gov.br/

11. Ministério da Saúde (BR). Plano de contingência nacional para infecção humana pelo novo Coronavírus COVID-19, 1a ed. Brasília; 2020 [cited 2020 Apr 14]. Available from: https://portalarquivos2.saude.gov.br/images/pdf/2020/ fevereiro/13/plano-contingencia-coronavirus-COVID19.pdf

12. Secretaria Estadual de Saúde do Estado da Bahia (BR) [Internet]. Salvador: SMS, c2020 [cited 2020 Apr 14]. Central Integrada de Controle e Comando da Saúde; [about 1 screen]. Available from: https://bi.saude.ba.gov.br/ transparencia/

13. Secretaria da Saúde [Rio Grande do Sul] (BR) [Internet]. Porto Alegre: SES; c2020 [cited 2020 Apr 20]. Atenção Básica ou Primária - principal porta de entrada para o Sistema Único de Saúde (SUS); [aprox. 1 tela]. Available from: https://saude.rs.gov.br/atencao-basica-ou-primaria-principal-porta-deentrada-para-0-sistema-unico-de-saude-sus

14. Vygotsky LS. A formação social da mente. 7. ed. São Paulo: Martins Fontes; 2007.

15. Secretaria Municipal da Saúde do Salvador. Diretoria Estratégica de Planejamento e Gestão (DEPG). Plano Municipal de Saúde 2018-2021. Salvador: Secretaria Municipal da Saúde; 2018 [cited 2020 Jun 04]. v. 1. Available from: http://www. saude.salvador.ba.gov.br/secretaria/wp-content/uploads/sites/2/2018/12/ Plano-Municipal-de-Sa\%C3\%BAde-2018-2021-VOLUME-I_aprovado-peloCMS-21.11.pdf

16. Lucci MA. A proposta de Vygotsky: a psicologia sócio-histórica. Professorado. 2006 [citado 2020 Jul 09];10(2):1-11. Available from: https://www.ugr. es/ recfpro/rev102COL2port.pdf

17. Schroeder E, Ferrari N, Maestrelli SRP. A construção dos conceitos científicos em aulas de ciências: a teoria histórico-cultural do desenvolvimento como referencial para análise de um processo de ensino sobre sexualidade humana. Alexandria: R Educ Cienc Tecnol. 2009 [cited 2020 Jul 09];3(1):21-49. Available from: https://periodicos.ufsc.br/index.php/alexandria/article/view/38014

18. Lumer $S$, Rodrigues PHA. 0 papel da saúde da família na atenção às urgências. Rev APS. 2011 [cited 2020 Apr 15];14(3):289-95. Available from: https://periodicos.uff.br/index.php/aps/article/view/14607

19. Ministério da Saúde (BR). Informe Técnico da 22a Campanha Nacional de Vacinação contra a Influenza. Brasília, DF; 2020 [cited 2020 Jul 08]. Available from: https://sbim.org.br/images/files/notas-tecnicas/informe-tecnico-mscampanha-influenza-2020-final.pdf 
20. World Health Organization (CH) [Internet]. Geneva: WHO; c2018-2020 [cited 2020 Jul 08]. Influenza (seasonal); [about 1 screen] Available from: https:// www.who.int/en/news-room/fact-sheets/detail/influenza-(seasonal)

\section{- Authorship contribution:}

Lélia Mendes Sobrinho de Oliveira: Substantial participation in the conceptualization of the manuscript; Substantial participation in data curation, research and methodology; Participation in project management, supervision, visualization and drafting.

Nildete Pereira Gomes: Substantial participation in the conceptualization, investigation and methodology of the manuscript; Participation in project management, supervision, visualization and drafting.

Emanuela Santos Oliveira: Substantial participation in the conceptualization and investigation of the manuscript; Participation in the visualization and draft of the essay.

Alice de Andrade Santos: Substantial participation in the conceptualization, investigation and formal analysis of the manuscript; Participation in the visualization and draft of the essay.

Larissa Chaves Pedreira: Participation in project management, review and editing of the manuscript.

\section{- Corresponding author:}

Lélia Mendes Sobrinho de Oliveira

E-mail: leliasobrinho79@gmail.com
21. Bacurau AGM, Ferraz RO, Donalisio MR, Francisco PMSB. Mortalidade por doenças cerebrovasculares em idosos e a vacinação contra a influenza: Estado de São Paulo, Brasil, 1980-2012. Cad Saúde Pública. 2019;35(2):e00145117. doi: https://doi.org/10.1590/0102-311x00145117

\section{Associate editor:}

Dagmar Elaine Kaiser

\section{Editor-in-chief:}

Received: 20.05.2020

Maria da Graça Oliveira Crossetti 